\title{
Massilia aerilata sp. nov., isolated from an air sample
}

\author{
Hang-Yeon Weon, ${ }^{1}$ Byung-Yong Kim, ${ }^{2}$ Jung-A Son, ${ }^{1}$ Han Byul Jang, ${ }^{2}$ \\ Sung Kee Hong, ${ }^{3}$ Seung-Joo $\mathrm{Go}^{2}$ and Soon-Wo Kwon ${ }^{2}$
}

\begin{abstract}
Correspondence
Soon-Wo Kwon

swkwon@rda.go.kr
\end{abstract}

\author{
${ }^{1}$ Applied Microbiology Division, National Institute of Agricultural Science and Technology, Rural \\ Development Administration, Suwon 441-707, Republic of Korea \\ ${ }^{2}$ Korean Agricultural Culture Collection, Microbial Genetics Division, National Institute of \\ Agricultural Biotechnology, Rural Development Administration, Suwon 441-707, Republic of Korea \\ ${ }^{3}$ Plant Pathology Division, National Institute of Agricultural Science and Technology, Rural \\ Development Administration, Suwon 441-707, Republic of Korea
}

The genus Massilia was first proposed with the species Massilia timonae for a strain isolated from the blood of an immunocompromised patient with cerebellar lesions ( $\mathrm{La}$ Scola et al., 1998). Since then, five further species have been described: Massilia dura, M. albidiflava, M. plicata, M. lutea and M. aurea (Zhang et al., 2006; Gallego et al., 2006). The genus was characterized as comprising motile, rod-shaped bacteria containing $\mathrm{C}_{16: 0}$ and summed feature 3 as the major fatty acids and Q-8 as the predominant isoprenoid quinone and showing relatively high $\mathrm{G}+\mathrm{C}$ contents (62$67 \mathrm{~mol} \%)$.

In the course of a study on the bacterial populations in air samples, we isolated a yellow-coloured bacterial strain. Air samples were collected in the Suwon region by using an MAS-100 air sampler (single-stage multiple-hole impactor; Merck) that contained Petri dishes with R2A medium (BBL) supplemented with cycloheximide (Sigma) at $200 \mu \mathrm{g} \mathrm{ml}^{-1}$. After sampling, plates were incubated at $28{ }^{\circ} \mathrm{C}$ for 5 days and strain $5516 \mathrm{~S}-11^{\mathrm{T}}$ was recovered.

Cell morphology and motility were observed with phasecontrast microscopy and transmission electron microscopy, using cells negatively stained with $0.5 \%$ uranyl acetate after growth on R2A for 2 days. The methods of

The GenBank/EMBL/DDBJ accession number for the 16S rRNA gene sequence of strain $5516 \mathrm{~S}-11^{\top}$ is EF688526.
Smibert \& Krieg (1994) were used to determine the following: Gram stain, catalase and oxidase activities and hydrolysis of CM-cellulose, casein, chitin from crab shells, DNA, hypoxanthine, pectin, starch, Tween 80 , tyrosine and xanthine. The optimum $\mathrm{pH}$ for growth was examined in $\mathrm{R} 2 \mathrm{~A}$ broth adjusted to various $\mathrm{pHs}(\mathrm{pH} 4-10$, in increments of $1.0 \mathrm{pH}$ unit). The tolerance of strain $5516 \mathrm{~S}-11^{\mathrm{T}}$ to various $\mathrm{NaCl}$ concentrations $(0,1,2,3$ and $5 \%$, w/v) was tested in R2A broth. The optimum temperature for growth of the strain was examined at various temperatures (5$45^{\circ} \mathrm{C}$, in increments of $5{ }^{\circ} \mathrm{C}$ ) on R2A agar. Growth under anaerobic conditions was determined after incubating the strain in a GasPak (BBL) jar at $30{ }^{\circ} \mathrm{C}$ for 15 days. Physiological and biochemical properties were investigated further using API ZYM, API 20NE and API ID 32GN kits (bioMérieux). Commercial tests were generally performed according to the manufacturer's instructions. The API ZYM test strip was read after $4 \mathrm{~h}$ incubation at $37{ }^{\circ} \mathrm{C}$ and the other API test strips were examined after 5 days at $28{ }^{\circ} \mathrm{C}$. Phenotypic data for strain $5516 \mathrm{~S}-11^{\mathrm{T}}$ and recognized Massilia species are compared in Table 1.

Whole-cell fatty acids were analysed according to the standard protocol of the MIDI/Hewlett Packard Microbial Identification System (Sasser, 1990). Isoprenoid quinones were extracted and analysed as described by Groth et al. (1996). The DNA G + C content was determined by means 
Table 1. Differential phenotypic characteristics of strain $5516 \mathrm{~S}-11^{\top}$ and type strains of Massilia species

Strains: 1, 5516S-11 ${ }^{\mathrm{T}}$; 2, M. albidiflava DSM $17472^{\mathrm{T}} ; 3$, M. aurea DSM $18055^{\mathrm{T}} ; 4$, M. dura DSM $17513^{\mathrm{T}} ; 5$, M. lutea DSM 17473 ${ }^{\mathrm{T}}$; 6 , M. plicata DSM $17505^{\mathrm{T}}$; 7, M. timonae DSM $16850^{\mathrm{T}}$. Data were obtained in this study unless indicated. All strains are catalase-positive. In API $20 \mathrm{NE}$ test strips, all strains are positive for hydrolysis of aesculin and gelatin but negative for indole production, glucose fermentation and arginine dihydrolase. In API 20NE test strips, all strains assimilate D-mannose and maltose but not D-mannitol or capric acid. In API ZYM test strips, all strains are positive for alkaline phosphatase, esterase (C4), esterase lipase (C8), leucine arylamidase, valine arylamidase, acid phosphatase and naphthol-AS-BIphosphohydrolase but negative for lipase (C14), trypsin, $\alpha$-chymotrypsin, $\beta$-glucuronidase, $N$-acetyl- $\beta$-glucosaminidase, $\alpha$-mannosidase and $\alpha$ fucosidase. +, Positive; (+), weakly positive; - , negative.

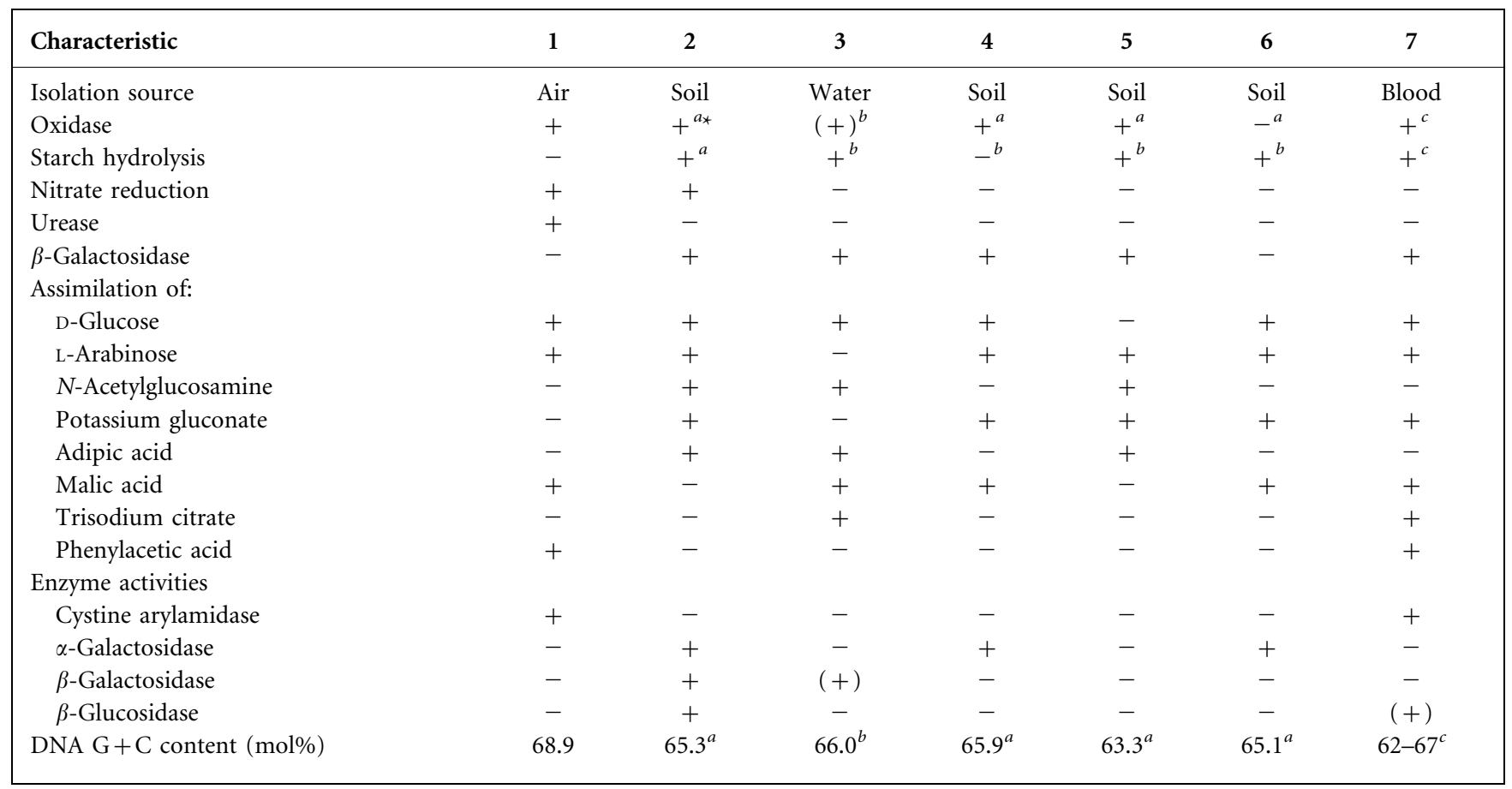

${ }^{\star}$ Data from: $a$, Zhang et al. (2006); b, Gallego et al. (2006); c, Lindquist et al. (2003).

of HPLC analysis of deoxyribonucleosides, as described by Mesbah et al. (1989), using a reversed-phase column (Supelcosil LC-18 S; Supelco).

The major fatty acids of strain $5516 \mathrm{~S}-11^{\mathrm{T}}$ were summed feature $3 \quad\left(\mathrm{C}_{16: 1} \omega 7 c /\right.$ iso- $\left.\mathrm{C}_{15: 0} \quad 2-\mathrm{OH} ; 35.2 \%\right), \mathrm{C}_{16: 0}$ $(30.6 \%)$ and $C_{18: 1} \omega 7 c(11.7 \%)$ (Table 2$)$. The predominant isoprenoid quinone was Q-8. The DNA G+C content of strain $5516 \mathrm{~S}-11^{\mathrm{T}}$ was $68.9 \mathrm{~mol} \%$.

The 16S rRNA gene was amplified by using a PCR with primers $\mathrm{fD} 1$ and rP2 (Weisburg et al., 1991) on colonies; the entire PCR fragment was directly sequenced (Hiraishi, 1992). The closest known relatives of the novel isolate were determined by performing GenBank/EMBL/DDBJ database searches. After multiple alignments of data by CLUSTAL $\mathrm{W}$ (Thompson et al., 1994), the software package MEGA, version 3.1 (Kumar et al., 2004), was used for all analyses. Phylogenetic dendrograms were constructed using the neighbour-joining (Saitou \& Nei, 1987) and maximumparsimony (Fitch, 1971) methods with bootstrap values based on 1000 replications. DNA-DNA hybridization was carried out as described by Seldin \& Dubnau (1985). Probe labelling was conducted by using the non-radioactive DIG High Prime system (Roche); hybridized DNA was visualized using the DIG luminescent detection kit (Roche). DNA-DNA relatedness was quantified by using a densitometer (Bio-Rad).

A phylogenetic analysis based on 16S rRNA gene sequences showed that strain $5516 \mathrm{~S}-11^{\mathrm{T}}$ falls within the genus Massilia (Fig. 1). Strain 5516S-11 $1^{\mathrm{T}}$ exhibited 16S rRNA gene sequence similarity values of 95.1-97.2\% with respect to the type strains of recognized Massilia species, the highest similarity value $(97.2 \%)$ being found with the sequence of $M$. aurea DSM $18055^{\mathrm{T}}$. Although the two recognized species of the genus Telluria also clustered with members of the genus Massilia, their phylogenetic position was unstable (low bootstrap values) (Fig. 1). Strain 5516S$11^{\mathrm{T}}$ showed lower levels of sequence similarity $(<95 \%)$ with respect to the two Telluria species than with respect to Massilia species. The maximum-parsimony tree also supported the clustering of $5516 \mathrm{~S}-11^{\mathrm{T}}$ and $M$. aurea DSM $18055^{\mathrm{T}}$ shown in the neighbour-joining tree. The value for DNA-DNA hybridization between strain 5516S- 
Table 2. Fatty acid compositions of strain $5516 \mathrm{~S}-11^{\top}$ and type strains of Massilia species

Strains: $1,5516 \mathrm{~S}-11^{\mathrm{T}} ; 2$, M. albidiflava DSM $17472^{\mathrm{T}} ; 3$, M. aurea DSM $18055^{\mathrm{T}}$; 4, M. dura DSM $17513^{\mathrm{T}}$; 5, M. lutea DSM $17473^{\mathrm{T}}$; 6, M. plicata DSM $17505^{\mathrm{T}}$ (data from Zhang et al., 2006); 7, M. timonae DSM $16850^{\mathrm{T}}$. All data except those for M. plicata DSM $17505^{\mathrm{T}}$ were obtained in this study. All strains except M. albidiflava DSM $17472^{\mathrm{T}}$ were grown at $28{ }^{\circ} \mathrm{C}$ on R2A for 2 days; cells of M. albidiflava DSM $17472^{\mathrm{T}}$ were harvested after growth at $28{ }^{\circ} \mathrm{C}$ on trypticase soy agar for 2 days.,$-<1 \%$ or not detected.

\begin{tabular}{|lccccccc|}
\hline Fatty acid & $\mathbf{1}$ & $\mathbf{2}$ & $\mathbf{3}$ & $\mathbf{4}$ & $\mathbf{5}$ & $\mathbf{6}$ & $\mathbf{7}$ \\
\hline $\mathrm{C}_{10: 0} 3-\mathrm{OH}$ & 4.7 & 7.0 & 6.0 & 5.5 & 5.7 & 10.1 & 4.6 \\
$\mathrm{C}_{12: 0}$ & 3.4 & 5.3 & 4.4 & 3.9 & 4.0 & 7.1 & 3.3 \\
$\mathrm{C}_{12: 0} 2-\mathrm{OH}$ & - & - & - & - & - & 1.6 & 2.2 \\
$\mathrm{C}_{14: 0}$ & 1.9 & 2.6 & 2.0 & 1.1 & 1.2 & - & - \\
$\mathrm{C}_{14: 0} 2-\mathrm{OH}$ & 2.5 & 2.4 & 2.5 & 2.6 & 2.9 & 6.1 & - \\
$\mathrm{C}_{16: 0}$ & 30.6 & 23.4 & 27.2 & 27.5 & 26.6 & 25.1 & 30.5 \\
$\mathrm{C}_{17: 0}$ cyclo & 6.1 & - & - & - & - & - & 3.7 \\
$\mathrm{C}_{18: 1} \omega 7 c$ & 11.7 & 7.4 & 7.92 & 7.03 & 7.8 & 11.7 & 7.87 \\
Summed & 35.2 & 46.0 & 48.6 & 52.0 & 51.1 & 36.9 & 47.0 \\
feature $3 *$ & & & & & & & \\
\hline
\end{tabular}

${ }^{*}$ Summed feature 3 included $\mathrm{C}_{16: 1} \omega 7 c$ and/or iso- $\mathrm{C}_{15: 0}$ 2-OH.

$11^{\mathrm{T}}$ and M. aurea DSM $18055^{\mathrm{T}}$ was $32 \%$. This level of relatedness was significantly lower than the threshold accepted as the phylogenetic definition of a species (Wayne et al., 1987).

As shown in Tables 1 and 2, strain $5516 \mathrm{~S}-11^{\mathrm{T}}$ can be differentiated from other Massilia species on the basis of basic biochemical properties, assimilation profiles and the presence of a moderate amount $(6.1 \%)$ of $\mathrm{C}_{17: 0}$ cyclo. In particular, strain $5516 \mathrm{~S}-11^{\mathrm{T}}$ could be distinguished from its closest phylogenetic relative, M. aurea DSM $18055^{\mathrm{T}}$, by their very different assimilation patterns and enzyme activities; the former showed a negative reaction for starch hydrolysis and $\beta$-galactosidase and demonstrated nitrate reduction and urease activity. Therefore, on the basis of the phenotypic, phylogenetic and genetic data, strain 5516S$11^{\mathrm{T}}$ should be classified within the genus Massilia as a member of a novel species, for which the name Massilia aerilata sp. nov. is proposed.

\section{Description of Massilia aerilata sp. nov.}

Massilia aerilata (ae.ri.la'ta. L. n. aer air; L. part. adj. latus - $a$-um carried; N.L. fem part. adj. aerilata airborne).

Cells are aerobic, Gram-negative, rod-shaped bacteria, 0.7$10 \mu \mathrm{m}$ wide and $1.5-3.0 \mu \mathrm{m}$ long, and are motile by means of single polar flagella. Colonies are light yellow, round and convex with clear margins. Grows well on R2A, nutrient agar (Difco) and trypticase soy agar (Difco) but does not grow on MacConkey agar (Difco). Catalase- and oxidasepositive. Grows at $5-35{ }^{\circ} \mathrm{C}$ (optimum, $28{ }^{\circ} \mathrm{C}$ ) on $\mathrm{R} 2 \mathrm{~A}$. The $\mathrm{pH}$ range for growth is 5-9 (optimum, $\mathrm{pH}$ 6-8). Grows with $0-1 \% \mathrm{NaCl}(\mathrm{w} / \mathrm{v})$. Degrades casein, hypoxanthine, tyrosine and Tween 80, but does not degrade chitin, DNA, pectin, starch or xanthine. Assimilates L-alanine, Larabinose, D-glucose, glycogen, L-histidine, 3-hydroxybutyric acid, malic acid, maltose, D-mannose, phenylacetic acid, L-proline and L-serine. Weakly assimilates propionic acid and sodium acetate. Does not assimilate $N$-acetylglucosamine, adipic acid, capric acid, L-fucose, 3-hydroxybenzoic acid, 4-hydroxybenzoic acid, inositol, itaconic acid, lactic acid, D-mannitol, melibiose, potassium gluconate, potassium 2-ketogluconate, potassium 5-ketogluconate, L-rhamnose, D-ribose, sucrose, sodium malonate, suberic acid, salicin, D-sorbitol, trisodium citrate or valeric acid (API 20NE and API ID 32GN test strips). The major fatty acids are summed feature $3\left(\mathrm{C}_{16: 1} \omega 7 c /\right.$ iso- $\mathrm{C}_{15: 0} 2$ $\mathrm{OH} ; 35.2 \%), \mathrm{C}_{16: 0}(30.6 \%)$ and $\mathrm{C}_{18: 1} \omega 7 c(11.7 \%)$. The predominant ubiquinone is Q- 8 . The DNA G + C content of the type strain is $68.9 \mathrm{~mol} \%$. The species is most closely related phylogenetically to $M$. aurea.

The type strain, $5516 \mathrm{~S}-11^{\mathrm{T}}$ (=KACC $12505^{\mathrm{T}}=\mathrm{DSM}$ $\left.19289^{\mathrm{T}}\right)$, was isolated from an air sample collected from Suwon, Republic of Korea.

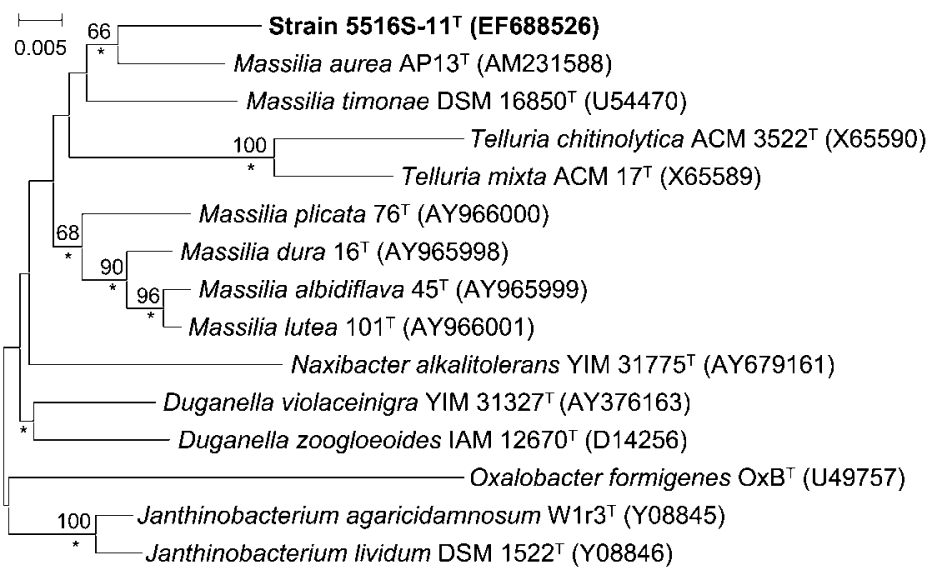

Fig. 1. Neighbour-joining phylogenetic tree, based on 16S rRNA gene sequences, showing the relationships between strain 5516S$11^{\top}$ and closely related species. Asterisks indicate that the corresponding branches were also recovered in the maximum-parsimony tree. Bootstrap percentages are shown at branch points; percentages below $50 \%$ are not indicated. Bar, 0.005 changes per nucleotide position. 


\section{Acknowledgements}

This work was supported by a grant (no. 06-4-11-19-1) from the National Institute of Agricultural Biotechnology, Rural Development Administration, Republic of Korea.

\section{References}

Fitch, W. M. (1971). Toward defining the course of evolution: minimum change for a specific tree topology. Syst Zool 20, 406-416.

Gallego, V., Sánchez-Porro, C., García, M. T. \& Ventosa, A. (2006). Massilia aurea sp. nov., isolated from drinking water. Int J Syst Evol Microbiol 56, 2449-2453.

Groth, I., Schumann, P., Weiss, N., Martin, K. \& Rainey, F. A. (1996). Agrococcus jenensis gen. nov., sp. nov., a new genus of actinomycetes with diaminobutyric acid in the cell wall. Int J Syst Bacteriol 46, 234 239.

Hiraishi, A. (1992). Direct automated sequencing of $16 \mathrm{~S}$ rDNA amplified by polymerase chain reaction from bacterial cultures without DNA purification. Lett Appl Microbiol 15, 210-213.

Kumar, S., Tamura, K. \& Nei, M. (2004). MEGA3: integrated software for molecular evolutionary genetics analysis and sequence alignment. Brief Bioinform 5, 150-163.

La Scola, B., Birtles, R. J., Mallet, M. N. \& Raoult, D. (1998). Massilia timonae gen. nov., sp. nov., isolated from blood of an immunocompromised patient with cerebellar lesions. J Clin Microbiol 36, 28472852.

Lindquist, D., Murrill, D., Burran, W. P., Winans, G., Janda, J. M. \& Probert, W. (2003). Characteristics of Massilia timonae and Massilia timonae-like isolates from human patients, with an emended description of the species. J Clin Microbiol 41, 192-196.
Mesbah, M., Premachandran, U. \& Whitman, W. B. (1989). Precise measurement of the $\mathrm{G}+\mathrm{C}$ content of deoxyribonucleic acid by highperformance liquid chromatography. Int J Syst Bacteriol 39, 159-167.

Saitou, N. \& Nei, M. (1987). The neighbor-joining method: a new method for reconstructing phylogenetic trees. Mol Biol Evol 4, 406425.

Sasser, M. (1990). Identification of bacteria by gas chromatography of cellular fatty acids, MIDI Technical Note 101. Newark, DE: MIDI Inc.

Seldin, L. \& Dubnau, D. (1985). Deoxyribonucleic acid homology among Bacillus polymyxa, Bacillus macerans, Bacillus azotofixans, and other nitrogen-fixing Bacillus strains. Int J Syst Bacteriol 35, 151-154.

Smibert, R. M. \& Krieg, N. R. (1994). Phenotypic characterization. In Methods for General and Molecular Bacteriology, pp. 607-654. Edited by P. Gerhardt, R. G. E. Murray, W. A. Wood \& N. R. Krieg. Washington, DC: American Society for Microbiology.

Thompson, J. D., Higgins, D. G. \& Gibson, T. J. (1994). ClUSTAL W: improving the sensitivity of progressive multiple sequence alignment through sequence weighting, position-specific gap penalties and weight matrix choice. Nucleic Acids Res 22, 4673-4680.

Wayne, L. G., Brenner, D. J., Colwell, R. R., Grimont, P. A. D., Kandler, O., Krichevsky, M. I., Moore, L. H., Moore, W. E. C., Murray, R. G. E. \& other authors (1987). International Committee on Systematic Bacteriology. Report of the ad hoc committee on reconciliation of approaches to bacterial systematics. Int J Syst Bacteriol 37, 463-464.

Weisburg, W. G., Barns, S. M., Pelletier, D. A. \& Lane, D. J. (1991). 16 S ribosomal DNA amplification for phylogenetic study. J Bacteriol 173, 697-703.

Zhang, Y.-O., Li, W.-J., Zhang, K.-Y., Tian, X.-P., Jiang, Y., Xu, L.-H., Jiang, C.-L. \& Lai, R. (2006). Massilia dura sp. nov., Massilia albidiflava sp. nov., Massilia plicata sp. nov. and Massilia lutea sp. nov., isolated from soils in China. Int J Syst Evol Microbiol 56, 459463. 